\title{
Cognitive-pragmatic Interpretation of Blending Characters in V. V. Nabokov's Prose
}

\author{
Y. N. Vasilishina \\ Karagandy Academy of the Ministry of Internal Affairs of the Republic of Kazakhstan \\ named Barimbek Beisenov, Kazakhstan, 100021, Karagandy, Ermekov Street, 124. Email: \\ helen-vasilishin@mail.ru
}

Received March 05, 2017; Revised May 1, 2017; Accepted May 5, 2017; Published May 7, 2017.

\begin{abstract}
Based on the research made, the author proposes to use cognitive-pragmatic mechanism to construct implicit meanings having the purpose to interpret chosen blend characters in adequate manner. Usage of method on conceptual integration to make blends in story "Cloud, Castle, Lake" by V.V. Nabokov helped to determine communicative author personification. The work stresses that blend is not defined directly out of all parts of the basic space, but the result of transformation of the basic elements with consideration of mental structures, which appear in the process of story reading. Creation process of mental patterns is demonstrated, that helps to follow the transformation of images being "behind the words" in order to describe the reality. Such cognitive recipient abilities as memory, perception and inner representation of the knowledge help to construct blends in Nabokov V.V. discourse: "man - Russian - Ioann man", "man Jesus" and "man - Satan - doll".
\end{abstract}

Keywords: Implicit information, subtext, implicature, blend, blend image, conceptual integration, blending, mental space, original space, common space, literary discourse, decoding.

\section{Introduction}

The proposed work actualizes a list of problems of cognitive linguistics, pragmalinguistics as well as lexical semantics and is devoted to the analysis of the artistic discourse of Nabokov V. V. having the story "Cloud, Castle, Lake" as basis for research. Linguistic person of Nabokov V. V. is one of the biggest figures in literature of the XX century among the Russian figures. It is noted that an understanding of texts written by Nabokov V.V. is located in simple formula at first glance: reaching the destruction idea by linguistic text line. Choice made in favor of Nabokov V.V. prose as object for research can be explained by another factor as well: soul measurement of the character, review of character space as a separate world among other worlds leads to the shift of space borders and helps to define blend patterns as a result.

Artistic text is a cognitive-pragmatic phenomenon, which is characterized by cognitive generation of author consciousness as cognition field of recipient consciousness in the next turn. There are specific features of artistic text as follows: transformation of the objective world picture as well as social and cultural filling of artistic images (when subconsciousness things are explicated, implicit meanings). So, additional meaning nuances appear, which are considered as speech tactics with hidden influence on the addressee by author [Kuznetsova A.V., 2015, 55-67].

(c) AesthetixMS 2016. This Open Access article is published under a Creative Commons Attribution Non-Commercial 4.0 International License (http://creativecommons.org/licenses/by-nc/4.o/), which permits non-commercial re-use, distribution, and reproduction in any medium, provided the original work is properly cited. For citation use the DOI. For commercial re-use, please contact editor@rupkatha.com. 
However, recipient consciousness towards Nabokov texts is a cognitive problem, which can be resolved by a summary of various contextual features of the author-voice being heard clearly or heard as whisper to be hardly caught by the reader.

It is noted that a "person talking expresses own emotions in categorized communicative situations and can model the same towards the speech partner" [Shakhivskiy V.I., Korobkina, 2013, 180]. Pragmatic essence of the process on reading and understanding of Nabokov V.V. texts is concluded in constant following the twisted road of artistic text, catching the plot turn as well as role change taking place with author and characters in the author's compositions.

Researchers point out that the core of receptive approach is fully up to interpretation preferences of the recipient, which shall be based on context (intertextual, intratextual and extratextual) [Kozhanova V.Yu., 2010, pages 48-53]. That is why multivariate implicatures used by the author in the compositions actively do not suppose having decoding within the limits of a specific composition: they are coded many times, and their decoding is far away from the plot text line.

There is a big variety of methods on the analysis of implicatures of blend images. However, it is required to have a new approach with comprehensive analysis in order to get more reliable information, considering latent presence of implicit elements. In our opinion, such analytical method is the method on conceptual integration. We will attempt to prove efficiency of the method in cognitive linguistics in the process of blend construction within the limits of the present study.

\section{Method}

Authenticity of research results is achieved on the account of a complex methodology, which includes such main scientific methods as observation, analysis, synthesis, comparison, and semantic and differentiated types of analysis. Specific importance in our study can be given to the method of conceptual integration and contextual analysis as it provided decoding variation of the implicit text.

\section{Results}

We will illustrate the process of conceptual integration with an example of V.V. Nabokov's story "Cloud, Castle, Lake." The first type of blend image which had been selected by us: "man - Russian - man of John type."

In the story "Cloud, Castle, Lake," the main character has traits of Russianness - starting with name and ending with his inner nature. The character, it seems, Vasily Ivanovich (author exactly can't remember), going on a jaunt, borrowed an aluminum flask from friends, repaired his soles, bought a belt and a fancy-style flannel shirt. This attribute implicitly refers to the character of a Russian peasant, whose wardrobe is consisted of this kind of shirt, allowing him not to confine his movements working in the field and work at the farm. Refurbishing the soles does not appear by chance - the character is planning to spend the most part of time in walk.

However, the transformation of the character of the Russian male is that the author doesn't introduce the hero, typical for the Russian mentality associated with the Russia, but chunky ("short") person: 
"It (the shirt - rem. by E. N.), however, was too big for that cute, short man, who was always neatly trimmed, with intelligent and kind eyes".

Implicature that is contained in the above sentence is displayed by the surrounding lexical item "short" by other characteristics - cute, neatly trimmed, smart, kind, and it can be represented as follows: quite a harmless man who is only the trust and does not repel. Such a representation of the character is confirmed by the observations of K.O. Kasyanova, which indicates the following characteristics of the Russian people: gentleness, meekness, patience, willingness to suffering, which often leads to self-sacrifice (Kasyanova, 1994. P. 125).

"He slept badly the night before the departure. And why? Because he had to get up unusually early, and hence took along into his dreams the delicate face of the watch ticking on his night table; but mainly because that very night, for no reason at all, he began to imagine that this trip, thrust upon him by a feminine Fate in a low-cut gown, this trip which he had accepted so reluctantly, would bring him some wonderful, tremulous happiness. This happiness would have something in common with his childhood, and with the excitement aroused in him by Russian lyrical poetry, and with some evening sky line once seen in a dream, and with that lady, another man's wife, whom he had hopelessly loved for seven years-but it would be even fuller and more significant than all that. And besides, he felt that the really good life must be oriented toward something or someone".

Positive perception of events can refer to the space (Myalo, 1996), which supposes the following: whatever the good person makes cannot lead to the bad results. Implicature - positive uncertainty - arises due to lexical items "wonderful", "happiness", "best", and "good". However, composition turn with the manner of narration demonstrates contrast between the positive mood and fear arising from the subconsciousness: "He slept badly the night before the departure. And why?" The plot is introduced from the beginning of the paragraph - the character slept somehow badly. The author of the story says further that for no apparent reason (Vasily Ivanovich) it was beginning to seem for him.., that the trip would suddenly bring him. The effect of such meanings is promising and will subsequently be known.

Implicature of the target program described about the life of the character in the story lies in the last sentence - toward something or someone (usage of indefinite personal pronouns). The possibility that the author means the divine by realization of high values cannot be removed (in the following text addressing to the "vital").

Some persons, alas, attended the tour.

Implicature: more people, more opportunities to spend time more fun and interesting, as indicated by the interjection alas, introduces the idea of the unity of the Russian people, seeking to see in someone else's something close, that can occur by combining and uniting as many people (Myalo, 1996). However this quality, as we will see later, will be completely destroyed.

"The locomotive, working rapidly with its elbows, hurried through a pine forest, thenwith relief-among fields. Only dimly realizing as yet all the absurdity and horror of the situation, and perhaps attempting to persuade himself that everything was very nice, Vasily Ivanovich contrived to enjoy the fleeting gifts of the road. And indeed, how enticing it all is, what charm the world acquires when it is wound up and moving like a merry-goround! Which clarified things? <...> 
A crossing: a cyclist was waiting, one foot resting on the ground. Trees appeared in groups and singly, revolving coolly and blandly, displaying the latest fashions. The blue dampness of a ravine. A memory of love, disguised as a meadow.

$<\ldots>$ And after another hour of walk suddenly happiness was opened to him that he once thought about.

It was a pure, blue lake, with an unusual expression of its water. In the middle, a large cloud was reflected in its entirety. On the other side, on a hill thickly covered with verdure (and the darker the verdure, the more poetic it is), towered, arising from dactyl to dactyl, an ancient black castle. Of course, there are plenty of such views in Central Europe, but just this one, in the inexpressible and unique harmoniousness of its three principal parts, in its smile, in some mysterious innocence it had,-my love! my obedient one! — was something so unique, and so familiar, and so long-promised, and it so understood the beholder, that Vasily Ivanovich even pressed his hand to his heart, as if to see whether his heart was there in order to give it away".

Decoding implicit content of the fragment, we can point out that the Russian language comprehension is characterized by cosmism, that is, co-participation of persons in nature created by God. Therefore, it is necessary to treat it seriously, carefully, as close to the person with it (Myalo, 1996). This may explain impersonation - nature, subjects such person the locomotive, working rapidly with its elbows, hurried; expression of its water; smile, in some mysterious innocence it had.

Having the citation above as reference we note that implicature of excitement is transferred: by syntax and punctuation (exclamatory sentences, usage of emotionally marked lexical item as); by duplication of lexical item exactly - but exactly, exactly this; by inserted structure transmitting the emotional state - my love! my obedient!; by intensifying particle even and by love implicature - Vasily Ivanovich even pressed his hand to his heart, as if to see whether his heart was there in order to give it away (heart is given only to the sincerely loved one).

The representation of John the theologian, known to every Christian believer, as a healer who heals with prayer and faith, not drugs. Also he was distinguished for his sympathy and compassion to another, primarily focused on the mental state and not external, bodily. The character of the V.V. Nabokov story, Vasily Ivanovich absorbs like a sponge, perceives the world in all its colours and charms, manages to see even among the negative factors positive things, especially in nature, which appears before the eyes as the motion of the train.

"Some persons, alas, attended the tour. Who they will be, these drowsy - still unfamiliar to us - fellow travelers?"

The particle alas creates implicature of frustration of the main character.

Vasily Ivanovich was hoping for a big friendly company. It turned out that the company is not large and not so friendly, as will be explained subsequently. There is the implicit impatient expectation in the interrogative sentence.

The next blend character, highlighted by us, is integrated into a common theme - a religious theme: man - Jesus.

The blend character of a man - Jesus is presented in a number of scenes of the story up to the imagery crucifixion. It observes the scenes of bullying Vasily Ivanovich with parallels with a religious theme. The remaining members of the jaunt were openly mocking the main character 
(implicature - it is fun (jaunt) only for the group, but the fun was nearly turned to death for the main character). It is necessary to state that the image of Jesus and Vasily Ivanovich do not duplicate each other - the mission of Vasily Ivanovich is not of such significant scale - he's just one of those who went to rest. Jesus is the mission intended to save mankind. This is the phenomenon of blend character in the story.

"Realizing the whole stuff and horror of his situation just vaguely, and, perhaps trying to convince himself that everything is very nice".

Implicature - Vasiliy Ivanovich slowly began to realize that the journey would not finish well, and that there would be no positive emotions he wanted to get. Such an interpretation is made possible by filling adverbial - vaguely.

"He had with him: his favorite cucumber from the Russian store, a loaf of bread, and three eggs. <...>this was particularly easy, as all except Vasily Ivanovich had the same things. The cucumber amused everybody, was pronounced inedible, and was thrown out of the window. In view of the insufficiency of his contribution, Vasily Ivanovich got a smaller portion of sausage".

Implicature - the provision of the Russian man to a long journey - was unknown to the members of the German nationality group. In this regard, the share of the main character suffered - was thrown. The deprivation of the own share demonstrates blatant disregard and denigration of the dignity of the character.

"He was made to play cards. They pulled him about, questioned him, verified whether he could show the route of the trip on a map-in a word, all busied themselves with him, at first good-naturedly, and then with malevolence, which grew with the approach of night".

Implicature - bullying is created by a homogeneous predicate, the semantic content of which is based on the principle of gradation - characteristic discharge.

Periodically in the text of the story space V.V. Nabokov served implicit thought - it is coming very sad conclusion that, in fact, a harmless trip. Change of days - as it approaches the night - indicates that everything will happen exactly then. The image of the night in traditionally folklore is usually associated with mysticism, when the impure force turns out to show the power. Within romanticism the night symbolizes the mystery of life and death, is associated with death, sleep, darkness and chaos (Krasman, 2011. p. 19).

"Next day, from early morning to five o'clock in the afternoon, they raised dust along a highway, which undulated from hill to hill; then they took a green road through a dense fir wood. Vasily Ivanovich, as the least burdened, was given an enormous round loaf of bread to carry under his arm. How I hate you, our daily!"

The religious component is supported during the all text - implicature round bread presents readiness to make sacrifices. The epithet daily is not random. Daily - is something vital, necessary for the existence (Encyclopedic Dictionary of catchwords and expressions, 2003). Implicit: a reference to the Lord's Prayer: Our daily bread $<\ldots>$ The Body of Christ is given in the sacrament of the Holy Communion. In the gospel of Matthew we can read: "While they were eating, Jesus took bread, and blessed, and brake, and gave to the disciples, and said, take, eat; this is My Body..." (The Bible. The New Testament. The gospel of Matthew. Matt, 25, 26). The Lord warns further: "A man, who does not eat My Body and drink My Blood, will not inherit the Heaven Kingdom!" In the Psalms, King David exclaims: "And bread strengthens man's 
heart"(God-breathed Psalms of the Ishmael David, Ps. 103, 15). So the bread was considered sacred.

Not by chance Vasily Ivanovich got a huge round loaf of bread. This character, clearly different from the rest of the company will stand up for the victim in the final. The word huge also underlines the importance of Vasily Ivanovich as a victim.

"Three times Vasily Ivanovich lay down in filthy darkness, and three times it turned out that there was no one on the bench when he crawled out from under.

$<\ldots>$ It was a pure, blue lake, with an unusual expression of its water. In the middle, a large cloud was reflected in its entirety. On the other side, on a hill thickly covered with verdure (and the darker the verdure, the more poetic it is), towered, arising from dactyl to dactyl, an ancient black castle. Of course, there are plenty of such views in Central Europe, but just this one, in the inexpressible and unique harmoniousness of its three principal parts, in its smile, in some mysterious innocence it had,-my love! my obedient one!-was something so unique, and so familiar, and so long-promised, and it so understood the beholder, that Vasily Ivanovich even pressed his hand to his heart, as if to see whether his heart was there in order to give it away". The symbolism of the number three causes of implicature of the Christian Trinity: The Holy Trinity - the Father, the Son and the Holy Spirit. The figure of the lake, the cloud, the castle also supports the Trinity (in this case elements), enclosed in implicature: lake - water, cloud - air, castle - earth. Three of the selected images implicitly symbolize heaven, true happiness for the character that he acquired so casually and at the same time not accidentally.

“ - I shall complain,' wailed Vasily Ivanovich. - Give me back my bag. I have the right to remain where I want. Oh, but this is nothing less than an invitation to a beheading - he told me he cried when they seized him by the arms".

The implicature of close penalty is contained in the above segment. According to the Bible, when Pilate delivered Jesus Christ to the crucifixion, the soldiers raped over Him, they led Him to Calvary - and so Vasily Ivanovich was transmitted by the company, a desire which was by all means to stop him to find happiness, harmony. Implicature - an allusion to another novel by V. V. Nabokov "Invitation to a Beheading" has fallen by the way in the truest sense of the word. The leader said not random phrase:

$<\ldots>$ I am responsible for each of you and each of you will bring back dead or alive. Implicature contained in the last part of the phrase is a figure of speech dead or alive (in any state) - increases the penalty approximation Vasily Ivanovich.

"As soon as everyone had got into the car and the train had pulled off, they began to beat him-they beat him a long time, and with a good deal of inventiveness. It occurred to them, among other things, to use a corkscrew on his palms; then on his feet. The postoffice clerk, who had been to Russia, fashioned a knout out of a stick and a belt, and began to use it with devilish dexterity. Atta boy! The other men relied more on their iron heels, whereas the women were satisfied to pinch and to slap. All had a wonderful time."

The information was presented implicitly: the main character Vasily Ivanovich's penalty, since Christ, as if it redeems the sins of every representative of a joyride that all the time scoffed at the miserable gentle, kindest man. He had no opportunity and strength to confront the crowd, which was overcome by animal instinct. The image of Satan is also implicitly stated in the story began to act like the devil, deftly. Direct comparison like the devil points to cunning, skill, 
resourcefulness - attributes of Satan that are implemented in the character. The epithet iron also makes a direct association to the hooves of the devil.

Wounding is implicitly identical to the execution of Jesus when he was nailed to the cross, in the same places - the hand, the foot further increases the similarity with the description of the crucifixion.

"After returning to Berlin, he called on me; was much changed; sat down quietly, putting his hands on his knees; told his story; kept on repeating that he must resign his position, begged me to let him go, insisted that he could not continue, that he had not the strength to belong to mankind any longer."

Pose - hands on his knees, adverbum quietly - implicature of humility with the occurred circumstances. That, what can't be returned under any circumstances.

The semantics of a verb plus a noun with a preposition with the meaning of the image of the action - kept on repeating - contains implicature of urgency, almost pleading. Further there is a strengthening at the expense of the verb begged.

Brief communion must resign, semantically is an equivalent to the influence, oppression from outside enhances implicature extreme unwillingness to do anything he had not the strength to belong to mankind any longer. Implicature the burden of the human body, the desire to escape and to find solace, peace is what is truly wanted Vasily Ivanovich.

The third blend character in the story of V.V. Nabokov, is: man - Satan - doll.

"A lanky blond young man in Tyrolese garb stood out at once. He was burned the color of a cock's comb, had huge brick-red knees with golden hairs, and his nose looked lacquered. He was the leader furnished by the Bureau, and as soon as the newcomer had joined the group (which consisted of four women and as many men) he led it off toward a train lurking behind other trains, carrying his monstrous knapsack with terrifying ease, and firmly clanking with his hobnailed boots."

Implicature of the theatricality is found in the clothes of a leader - Tyrolean costume inappropriate attire for traveling Hiking through the woods. However, the fact that in Novorossiya in the XVIII century German coat (option Tyrolean costume) is an attribute of Satan. Implicature of Satan is contained in the entire description of the appearance of the leader of the joyride:

he was burned the color of a cock's comb, had huge brick-red knees with golden hairs - in the book of the revelation Satan is described as an impressive growth, the red dragon (color of a cock's comb). In the religious literature it describes that the devil is often in the form of a cock - hence the comparison with cockscomb; growth);

epithets: huge highlights growth (refers to Satan, who, as we know, was also high

hairy - Satan is often depicted with dense vegetation all over the body;

lacquered - contains implicature - unnatural, inhuman, artificial;

terrifying - implicitly indicate the Satan and his characteristics;

clanking with his hobnailed boots - Satan was depicted with hooves on his feet. 
The puppet idea of the other four heroes of joyride - are two Schultz and two girls highlighted in implicature - the absence of individuality in their characters:

$<\ldots>$ a middle-aged man, Schultz; a younger man, Schultz too, and two fidgety young women with big mouths and big rumps.

Another person of the trip implicitly presented, is similar to Satan - Schramm: there was also a dark young man by the name of Schramm, with lustreless eyes and a vague velvety vileness about his person and manners, who constantly switched the conversation to this or that attractive aspect of the excursion, and who gave the first signal for rapturous appreciation.

The epithet dark - implicit indication of the dark force to Satan and his Kingdom;

Lustreless eyes -the implicature "the inanimate, lifeless, dead";

Epithets vague velvety vileness - the implicature of disgusting by his whole appearance and manners.

Nomination of the character of "the Schramm" is also not accidental. Schramm, if you read back in Russian language is March, that is the "forward".

\section{Discussion}

A large body of works is devoted to an implicit side of the linguistic sign (Arnold, 2010; Baranov, 2007; Galperin, 2007; Goljakova, 2006; Dudorova, 2013; Makerova, 2013; Pushkareva, 2012; Radbil, 2012; Sissoko Duga, 2002; Sternin, 2011; Härtl, 2008; Grzesik, Jürgen, 2005). However, we did not find any papers about the inferences involved in constructing blend characters.

Implicit side of a linguistic sign always attracts more attention; since it is initially hidden, it is not supplied in finished form, and it requires decryption. While there is a degree of explicitness implicit, otherwise there would be no process of decoding, which depends on background knowledge, context of lexemes markers. Researcher Y. K. Pirogova gives the following definition of implicit information - this is the information that "is not explicitly expressed, but the need is retrieved by the addressee in interpreting messages (Pirogova, 20oo. p. 96).

Serebrennikova noted other characteristics of implicit, based on the interaction of the components of the text, therefore, becomes implicit in the subtext: "Implicit content or overtones called the hidden meaning of statements that does not coincide with the direct output from the correlation, comparing and contrasting the various components of the text" (Serebrennikova, 2002).

I. A. Sternin understands the undermeaning meaning as "implicit meaning, opening to the recipient of the text not immediately but as a result of some mental operations" (Sternin, 2011).

O. V. Voronushkina examines the presence of information, "either in the lexicalsemantic and grammatical phenomena or in the background knowledge and propositions, or in the intentional and motivational areas" (Voronushkina, 2014).

In the work of A. V. Bondarko it is noted that implicit knowledge manifests itself as a latent factor and it is included in the linguistic meaning in the semantically unmarked form of the conceptual categories of high level of generalization (Bondarko, 2006). 
In the presence of the speaker and the listener, a common cultural background is still one of the necessary conditions for the correct decryption of the implicit content. The so-called background knowledge, which refers to "knowledge of any reality that is implied, but not explicitly given away in the dialogue, and which are the basis of linguistic communication" (Kryukov, 1988).

It should be noted that at the present stage of development of the cognitive linguistics, the theory of conceptual integration or conceptual blending and the underlying theory of mental spaces have increasingly come up in the research of scientists. The evidence is paragraphs in the textbooks on cognitive linguistics (Ungerer, Schmidt, 2006.; Geeraerts, Cuyckens, 2007). Sometimes it can be themed items of leading linguistic magazines (No. 3/4 (2000) of the magazine "Cognitivelinguistics", "magazine of pragmatics" (2005. No. 10) and the magazine "language and literature" (2006. No. 1). And the founders of this theory Gilles Fauconnier and mark Turner argue that the application of conceptual blending in "matrix" form (double-scope blending) allows a person to go beyond the ability to understand and use the language and that is its unique feature in the thinking and perception of the world in general (Fauconnier, Turner, 2002).

Although some aspects of the theory of conceptual integration are subjected to a comprehensive analysis in a number of works (Gibbs, 2000; Harder, 2003; Brandt, 2005). It is not possible to isolate research, conceptualized as a theoretical system with the features of its methodology, evaluate the reliability of the obtained results.

The blend phenomenon became famous for a relatively little-known theory developed in the late twentieth century. Gilles Fauconnier's conceptual integration theory, or the theory of blending, is largely based on the principles of cognitive linguistics. According to the theory of G. Fauconnier, mental spaces are separate structures arising in the mind when a person thinks or says, isolating discourse and language structures. However, there are two types of mental spaces:

-the base used for the description of reality, and therefore known to both communicants,

-the designed - going beyond reality by appealing to possible measures by means of a temporary and local character markers.

Language serves as the necessary material by cognitive processing and generates a variety of implementations.

G. Fauconnier, together with M. Turner, understood the conceptual integration as the source of cognitive operation, with a clear structure, which includes the original space (input space), General space (spaces gerics) and mixed space (blended spaces) or blend. As we have seen, it introduced a new concept - blend, that cannot be deduced directly from all components of the original space, but borrowing only that part of the structure that is needed to build ultimately an understanding of the specific situation. The relationship of initial mental spaces is due to interdimensional display (cross-space mapping), whose function is to combine similar elements, prototypes («ccounterparts»), and general space (generic space), containing elements for both the original spaces elements a certain point of development of conceptual integration. The last are part of the blend (Fauconnier, Turner, 2006. P. 308).

So, it's impossible to talk about the direct projection of the structure of one of the standard spaces on a blend. Since blend is a new formation, synthesizing patterns belonging to two basic spaces. 
Analyzing the theory of conceptual integration of G. Fauconnier and M. Turner, V. Glebkin considers the cultural and historical part of the core in this theory, which the authors of the theory do not take into account. Also, as noted by the researcher, it is not advisable to consider the capacity for the generation of blends in the evolutionary aspect of humans (Glebkin, 2013).

\section{Conclusion}

Text is a multivariate phenomenon, which is analyzed considering research object. We determined meaning patterns of various volumes from pragmatic point of view in the text analyzed. Such patterns are under influence of the whole context, and the things behind the text are used in order to understand meaning of the patterns adequately.

Having the purpose to define blend images with a help of exploitation of cognitivepragmatic analysis towards implicatures, we had the necessity to explain on how implicatures could be the start point for demonstration of author world picture. We ascertained that implicatures have the main place in meaning of Nabokov V.V. texts, and they demand constant reflex from the reader and they are oriented towards decoding implementation. In other words, linguistic research on the mechanism of implicature activity requires combination of cognitive and pragmatic approaches.

The research has shown that meaning of text line with implicature presence is wider compared to the conventional meaning. Showing concealed meaning, implicatures add, transform and expand the borders of space and time defined in the text, and help to integrate into blends imagined space of possible text worlds. Lexemes with implicit meaning in Nabokov V.V. texts have pragmatic function and help to see patterns behind words-symbols, which define cognitivepragmatic mechanisms. Having dynamics, they transfer new meaning to the context, and the meaning demands specific decoding abilities from the recipient.

\section{References}

Arnold, I.V. Stylistics. Modern English language (Moscow: Flint. Science. p. 383, 2010).

Baranov, A.N. Linguistic examination of the text (Moscow: Flint-Sciences. p. 592, 2007).

Bondarko, A.V. Explicitness / implicitness in the common system of categorization of semantics, Semanticdiscursive studies of language: Explicitness / implicitness expression of meanings (Kaliningrad, p. 22-33, 2006).

Brandt, P.A. Mental spaces and cognitive semantics: A critical comment. Journal of Pragmatics, 37, 2005.

Dudorova, E.S. Implicit linguistic means and their participation in the development of the semantic content of the text. Cognitive studies of language, 13, pp. 703-712, 2013. Available at:

http://elibrary.ru/item.asp?id=18955415.

Serov V. Encyclopedic dictionary of catch phrase and expressions (Moscow: Lokid Press. p. 852, 2003).

Fauconnier, G., Turner, M. The Way We Think. Conceptual Blending and the Mind's Hidden Complexities (New York, pp. 389-396, 2002).

Fauconnier, G., Turner, M. Mental spaces: conceptual integration networks. Cognitive linguistics: basic readings. (Dirk Geeraerts (Ed.), Walter de Gruyter GmbH \& Co. KG, pp. 303-371, 2006).

Galperin, I.P. Text as an object of linguistic study (Moscow: KomKniga. p.144, 2007).

Geeraerts, D., Cuyckens, H. The Oxford handbook of cognitive linguistics (Oxford, 2007). 
Gibbs, R.W. Making good psychology out of blending theory. Cognitive linguistics, 3/4, p. 11, 2000.

Glebkin, V.V. Theory of conceptual integration of G. Fauconnier and M. Turner: the experience of system analysis. Questions of philosophy, 9, pp. 161-175, 2013.

Goljakova, L.A. The Ontology of implication and its objectification in the literarywork. Perm. p. 364, 2006.

Grzesik, Jürgen. Texte verstehen lernen. Neurobiologie und Psychologie der Entwicklung von Lesekompetenzen durch den Erwerb von textverstehenden Operationen (Münster: Waxmann Verlag. p. 396, 2005).

Harder, P. Mental spaces: exactly when do we need them? Cognitive Linguistics, 14, 1, 2003.

Härtl, H. Implizite Informationen. Sprachliche Ökonomie und interpretative Komplexität bei Verben (Berlin: Akademie Verlag GmbH. p. 216, 2008).

Kasyanova, K. About the Russian national character. Moscow, p. 265, 1994..

Kozhanova, V.Yu. Problem on Mediatext Reception as Factor of Author and Reader Interaction. Newspaper of Adigey State University. Lot 2. Philology and Art Science, 4, pp. 48-53, 2010.

Krasman, V.A. On the question of the specificity of "night of the chronotope" in European romanticism. Young scientist, 5(2), pp. 18-20, 2011.

Kryukov, A.N. Background knowledge and language communication. Ethnopsycholinguistics. (Y.A. Sorokin, I.Y. Markovina, A.N. Hooks (Eds.), Moscow: Nauka, pp. 19-34, 1988).

Kuznetsova, A.V. Additional Semantic Nuances as Cognitive and Pragmatic Phenomenon. International electronic collection of scientific works Cognition, Communication, Debate, 11: 55-67, 2015.

Makerova, S.R. Implicitness, implication, and lexical-morphological categories. Bulletin of Adygea state University. Series 2: Philology and art criticism, 3, pp. 69-75, 2013. Available at: http://elibrary.ru/item.asp?id=21142210.

Myalo, K.G. Russian ideal. Eurasia, 1(4), pp. 77-85, 1996.

Pirogova, Y.K. Promotional text: semiotics and linguistics. (Y.K. Pirogova, P.B. Parshin (Eds.), Moscow: ID Grabelnikova, p. 268, 2000).

Psalm of the prophet David. Brief the Psalter of St. Augustine (Orthodox publishing house "the Verb". 48o S. PS. 103, 15, 2015).

Pushkareva, N. Underscript meanings as components of the semantic structure of the prosaic text. Bulletin of Kalmyk Institute of humanitarian studies, RAS, 2, pp. 144-149, 2012. Available at: http://elibrary.ru/item.asp?id=17967409.

Radbill, T.B. Language anomalies in the literary text: Andrey Platonov and others (Moscow: Flint. p. 322, 2012).

Serebrennikova, E.S. Translation problems: implicit content in poetic communication. The tower of Babel: the Word. Text. Culture (Moscow, pp. 245-246, 2002).

Sissoko Duga. Implicitness as a way of actualization of the meaning in a literary text (Moscow, p.128, 2002).

Sternin, I.A. Analysis of undermeaning in the text. A textbook for undergraduates program "Psycholinguistics and languageminority" (Voronezh: Istoki. p. 66, 2011).

Shakhovskiy, V.I., Korobkina, N.I. Creative Language Function. Speach not in Nomination of New Context Notions. Isvestiya VGPU, 2. Classical Sciences lot, pp. 180-186, 2013.

The Bible. The New Testament. The gospel of Matthew. Matt, 25, 26.

Ungerer F., Schmid H.-J. An introduction to cognitive linguistics (New York, 2006).

Voronushkina, O.V. The hidden information and the way of explication. Bulletin of the Altai state pedagogical Academy. Ser.: Humanities, 21, pp. 62-67, Barnaul, 2014. 